\title{
Efficacy of traditional products on the biochemical aspects of stored mungbean infested with Callosobruchus maculatus (Fabricius)
}

\author{
Jagtar Singh, D. K. Sharma and Jasreet Kaur* \\ Department of Entomology, Punjab Agricultural University, Ludhiana-141004 (Punjab), INDIA \\ *Corresponding author. E-mail: jasreetgill21@gmail.com
}

Received: November 8, 2016; Revised received: April 30, 2017; Accepted: September 30, 2017

\begin{abstract}
The effect of traditional products viz. turmeric powder, turmeric grits, garlic powder along with standard check ( $7 \mathrm{~cm}$ layer of sand on the top of stored seed) was evaluated on the biochemical aspects of stored mungbean [Vigna radiata (L.)] infested with Callosobruchus maculatus (Fabricius). Treatments with garlic powder at $1.5 \%$ concentration recorded significantly less egg laying (2.00), less larval penetration $(5.00 \%)$, less adult emergence $(1.02 \%)$ as compared to other treatments. Alcoholic acidity increased significantly from 0.51 to $0.59,0.46$ to 0.55 and 0.38 to $0.49 \%$ by turmeric powder at $0.5,1.0$ and $2.0 \%$ concentration, respectively, as compared to control samples. Garlic powder was found to be most effective in checking uric acid at concentration of $1.5 \%$ during four months of storage, followed by turmeric powder @ $2.0 \%$ and turmeric grits @ $1.0 \%$. Order of effectiveness of used traditional products was garlic powder> turmeric powder>turmeric grits.
\end{abstract}

Keywords: Alcoholic acidity, C. maculatus, Mungbean, Storage, Traditional products

\section{INTRODUCTION}

Pulses are the most important food crops after cereals. Among these, mungbean is one of the major grain legume crops native to Indian subcontinent. It is the third most popular pulse crop cultivated throughout India, consumed as a whole, dehulled and sprouted grain for a variety of dishes, meals and also as animal feed. In India it was covering an area of 3.02 mha with total production of $1.50 \mathrm{mt}$ during 2014-15. It was cultivated over an area of 4.0 thousand hectares, producing 3.3 thousand tonnes with average yield of $833 \mathrm{~kg}$ per hectare in Punjab State in 2014-15 (Anonymous, 2014). Pulse beetle, Callosobruchus maculatus (Fabricius) (Bruchidae: Coleoptera) is a cosmopolitan, polyphagus and multi voltine species well known for its pronounced dimorphism (Pajni, 1987). These species caused maximum damage to stored cowpea (68.2\%) followed by mothbean (53.7\%) and mungbean (50.3\%) (Ramazan et al., 1990). During storage, pulses undergo some chemical changes due to the presence of insects which alter the flavor, nutritive value, marketability and acceptability of pulses. Alcoholic acidity is generated with the breakdown of protein into amino acids and also phytin into acid phosphates in the presence of enzyme phytase. Alcoholic acidity increases with increase in insect infestation and creates bitter and off flavor in the food grains. Changes in alcoholic acidity could be due to combined effects of free fatty acids, free amino acids and some organic acids present in the grain which get released during the storage by metabolic enzymes (Singh and Sharma 1981). Similarly, uric acid being an excretory product of the insects increases with the increase in insect population and indicates the hygienic quality of stored grain. Therefore, prevention of losses in stored products due to insects is of paramount importance. In the absence of any suitable control measure recommended against this pest, usually farmers resort to the use of fumigants leading to certain disadvantages like residues and development of resistance by insects (Mehrotra, 1991). This awareness has created worldwide interest in the re-examination of using plant derivatives and other traditional methods against agriculturally important insect-pests. But in our country yet not much work has been done to explore the possibilities of using plants and other traditional products as seed protectants. Hence, an attempt has been made to investigate the effect of traditional products against $C$. maculaus and the biochemical aspects of infested mungbean.

\section{MATERIALS AND METHODS}

The mungbean seed of variety PAU-911 was procured from PAU farm. The Pure culture of pulse beetle $(C$. maculatus) was obtained from Post-Harvest Technology Laboratory, Department of Processing and Food Engineering, PAU, Ludhiana. Different traditional products viz., turmeric powder @ 0.5, 1.0 and 2.0\%, turmeric grits@1.0,1.5 and 2.0\%,garlic powder@ $0.5,1.0$ and $1.5 \%$ along with recommended practice (cover the pulses stored in bulk with $7 \mathrm{~cm}$ sand layer) 
as standard check were used in this experimentation. There were total 11 treatments and each treatment was replicated thrice.To determine alcoholic acidity, one gram of ground sample was taken in $20 \mathrm{ml}$ of 90 per cent ethanol in a conical flask. Shaken for one hour and filtrate was obtained. This filtrate was titrated against standard alkali. Reagents used were neutral $90 \%$ ethanol, $\mathrm{N} / 40 \mathrm{NaOH}$ and phenolphthalein as indicator (AOAC, 1960). Alcoholic activity was calculated with the following formula:

Alcoholic acidity $\left(\mathrm{H}_{2} \mathrm{SO}_{4}\right)=\frac{24.52 \times \mathrm{VxN}}{\mathrm{W}}$
Where,
$\mathrm{V}=$ volume (in $\mathrm{mL}$ ) of alkali used; $\mathrm{N}=$ normality of the
alkali; $\mathrm{W}=$ weight (in gm) of the sample;
$24.52=\mathrm{H}_{2} \mathrm{SO}_{4}$ (Molecular weight)

Uric acid content: To determine uric acid content methodology modified by Thaper et al. (1973) was followed. Reagents used were $0.667 \mathrm{~N} \mathrm{H}_{2} \mathrm{SO}_{4}, 10 \%$ sodium tungstate $\left(\mathrm{Na}_{2} \mathrm{WO}_{4}\right)$, uric acid reagent and 14 per cent sodium carbonate. To extract uric acid, one gram ground sample of mung was taken and mixed with $50 \mathrm{ml}$ of distilled water. The contents were then boiled for about one minute to stop enzymatic activities. After cooling, $50 \mathrm{ml}$ of $0.02 \mathrm{~N}$ potassium hydroxide was added to it. The mixture was then shaken mechanically for one hour and kept in the refrigerator for 24 hours. The contents were then centrifuged at $2000 \mathrm{rpm}$ for 10 minutes. To the $50 \mathrm{ml}$ of clear supernatant $5 \mathrm{ml}$ of $10 \%$ sodium tungstate was added. After mixing the content, $5 \mathrm{ml}$ of $0.667 \mathrm{~N}$ $\mathrm{H}_{2} \mathrm{SO}_{4}$ was added to the precipitate the proteins present in the extract. The mixture was allowed to stand for 5 minute and then centrifuged at $2000 \mathrm{rpm}$. The clear supernatant containing uric acid was used for calorimetric determination of uric acid. To determine uric acid, three extraction tubes were set up. $5 \mathrm{ml}$ of filterate was added to the first, $4 \mathrm{ml}$ of working uric acid standard to the second and $4 \mathrm{ml}$ distilled water to the third. Then, $1 \mathrm{ml}$ of $14 \%$ sodium carbonate and 1 $\mathrm{ml}$ of uric acid reagent was added to each tube and allowed to stand for 15 minutes at room temperature. Sodium carbonate formed uric acid. Phosphomolybidic acid complex with uric acid which was blue in colour and was subjected to quantification at $680 \mathrm{~nm}$ setting the spectrophotometer to zero density with the blank. The uric acid content was calculated by the following formula:

mg of uric acid $=$ (Density of unknown $x$ Dilution factor $\mathrm{x}$ Concentration in the standard) / Density of standard

The observations on alcoholic activity, uric acid content were recorded at monthly interval for 4 months after giving treatments.

The data were analyzed statistically as per Completely Randomized Design (CRD) using computer programme
CPCS 1 (Cheema and Singh, 1990) after applying appropriate transformations wherever necessary.

\section{RESULTS AND DISCUSSION}

The data presented in table 1 revealed that significantly lower egg laying, less larval penetration and less adult emergence was observed in all the treated samples as compared to untreated control. No egg laying, larval penetration and adult emergence were observed in standard check treatments. Significantly lower egg-laying was observed in the treatments with garlic powder at $1.5 \%$ (2.00) followed by turmeric powder (a) 2.0\% and turmeric grits @ 2.0\%. Among different treatments, garlic powder at $1.5 \%$ concentration (5.00) recorded less larval penetration followed by turmeric powder at $2.0 \%$ (6.67) and turmeric grits at $2.0 \%$ (11.67). Developmental period of C. maculatus from egg to adult stage in treatments with turmeric powder, turmeric grits and garlic powder treated seeds (21 days) differed non-significantly from untreated control (20 days). Significantly less adult emergence was observed in treatments with garlic powder at $1.5 \%$ concentration (1.02) followed by turmeric powder at $2.0 \%$ and garlic powder at $1.0 \%$ (1.74). The data presented in table 2 revealed that alcoholic acidity increased significantly from 0.51 to $0.59,0.46$ to 0.55 and 0.38 to $0.49 \%$ by turmeric powder at $0.5,1.0$ and 2.0 per cent concentration, respectively, as compared to control sample. Thus showing a correlation between population build up and alcoholic acidity. A similar trend of this correlation between population build up and alcoholic acidity was observed in different concentrations of turmeric grits and garlic powder.

It is evident from the table 3 that uric acid content increased significantly from 37.52 to $67.64,36.24$ to 64.72 and 34.55 to $58.84 \mathrm{mg} / 100 \mathrm{~g}$ by turmeric powder treatment at $0.5,1.0$ and $2.0 \%$ concentration, respectively, as compared to control sample where it ranged from 41.82 to $97.95 \mathrm{mg} / 100 \mathrm{~g}$ during four months of storage. A similar trend was observed in case of treatments with turmeric grits and garlic powder. On overall basis, it was found that garlic powder was most effective treatment in checking uric acid at concentration of $1.5 \%$ during four months of storage, followed by turmeric powder@2.0\%. Turmeric grits @1.0\%was least effective in controlling uric acid development during storage.

In present investigation, different traditional products exhibited protectant activity against pulse beetle. This finding coincides with the finding of various other authors as; Kar et al. (2012) reported that the leaf powder of goat weed (Ageratum conyzoids) @ $2.5 \mathrm{~g} / 50 \mathrm{~g}$ of mungbean seeds was most effective against the egg laying of $C$. maculatus with minimum no. of eggs (1.2) while aak (Callotropis gigantia) leaf powder@2.5g/50g of mungbean seeds and bathua (Chenopodium album) leaf powder at same dose were 
Jagtar Singh et al. / J. Appl. \& Nat. Sci. 9 (4): 2110 - 2113 (2017)

Table 1. Efficacy of traditional products against various life stages of $C$. maculatus in stored mungbean

\begin{tabular}{lccccc}
\hline Treatment & $\begin{array}{c}\text { Concentration } \\
(\%) \mathbf{w} / \mathbf{w}\end{array}$ & Eggs/50 seeds & $\begin{array}{c}\text { Larval } \\
\text { penetration }\end{array}$ & $\begin{array}{c}\text { Development } \\
\text { period (days) }\end{array}$ & $\begin{array}{c}\text { Adult emergence } \\
(\%)\end{array}$ \\
\hline Turmeric powder & 0.5 & $5.33(1.66)$ & $21.67(3.07)$ & 21.00 & $2.46(0.89)$ \\
& 1.0 & $4.00(1.29)$ & $13.33(2.57)$ & 21.00 & $2.23(0.80)$ \\
Turmeric grits & 2.0 & $2.67(0.92)$ & $6.67(1.84)$ & 21.00 & $1.26(0.22)$ \\
& 1.0 & $7.33(1.98)$ & $26.67(3.28)$ & 21.00 & $2.98(1.09)$ \\
& 1.5 & $4.67(1.52)$ & $18.33(2.89)$ & 21.00 & $2.46(0.89)$ \\
Garlic powder & 2.0 & $3.33(1.15)$ & $11.67(2.44)$ & 21.00 & $1.97(0.68)$ \\
& 0.5 & $4.00(1.29)$ & $16.67(2.80)$ & 21.00 & $2.26(0.81)$ \\
& 1.0 & $3.33(1.15)$ & $11.67(2.44)$ & 21.00 & $1.74(0.55)$ \\
Standard check & 1.5 & $2.00(0.69)$ & $5.00(1.61)$ & 21.00 & $1.02(0.02)$ \\
Untreated control & - & 0.00 & 0.00 & 0.00 & 0.00 \\
CD (p=0.05) & - & $14.00(2.63)$ & $40.00(3.68)$ & 20.00 & $5.50(1.70)$ \\
\hline
\end{tabular}

Figures in the parentheses are $\log$ transformations

Table. 2. Effect of different concentrations of traditional products on alcoholic acidity of mungbean during four months of storage.

\begin{tabular}{|c|c|c|c|c|c|c|}
\hline \multirow[t]{3}{*}{ Treatment } & \multirow{3}{*}{$\begin{array}{l}\text { Concentration } \\
(\%) \text { w/w (B) }\end{array}$} & \multicolumn{4}{|c|}{ *Alcoholic acidity (\%) } & \multirow{3}{*}{ Mean } \\
\hline & & \multicolumn{4}{|c|}{ Storage period ** (MAT) (A) } & \\
\hline & & 1st & 2nd & 3rd & 4th & \\
\hline \multirow{3}{*}{$\begin{array}{l}\text { Turmeric } \\
\text { powder }\end{array}$} & 0.5 & 0.51 & 0.53 & 0.56 & 0.59 & 0.55 \\
\hline & 1.0 & 0.46 & 0.49 & 0.52 & 0.55 & 0.50 \\
\hline & 2.0 & 0.38 & 0.42 & 0.44 & 0.49 & 0.43 \\
\hline \multirow[t]{3}{*}{ Turmeric grits } & 1.0 & 0.52 & 0.55 & 0.57 & 0.61 & 0.56 \\
\hline & 1.5 & 0.47 & 0.50 & 0.54 & 0.57 & 0.52 \\
\hline & 2.0 & 0.43 & 0.46 & 0.49 & 0.53 & 0.48 \\
\hline \multirow[t]{3}{*}{ Garlic powder } & 0.5 & 0.45 & 0.47 & 0.52 & 0.54 & 0.49 \\
\hline & 1.0 & 0.42 & 0.45 & 0.47 & 0.52 & 0.46 \\
\hline & 1.5 & 0.37 & 0.40 & 0.43 & 0.48 & 0.42 \\
\hline Standard check & - & 0.30 & 0.32 & 0.35 & 0.40 & 0.34 \\
\hline Untreated control & - & 0.57 & 0.64 & 0.78 & 0.94 & 0.73 \\
\hline Mean & - & 0.44 & 0.47 & 0.51 & 0.56 & - \\
\hline $\mathrm{CD}(\mathrm{p}=0.05)$ & \multicolumn{5}{|c|}{$\mathrm{A}=0.01, \mathrm{~B}=0.01, \mathrm{AB}=0.03$} & \\
\hline
\end{tabular}

*Mean of three replications, **Months after treatment

least effective. Aslam et al., (2002) found that minimum number of adults of C.maculatus emerged in stored chickpea treated with cloves and black pepper as compared to cinnamon and red pepper (when each was applied @ 40g/dish) as the active components of both the spices (cloves and black pepper) affect the physiological behavior of pulse beetle such as oviposition activity, growth inhibition and adult mortality. Sharma et al., (2013) reported that treatments applied with neem oil@10 ml $/ \mathrm{kg}$ seed, mustard oil+groundnut oil @7.5 ml/kg seed, mustard oil + turmeric powder@3.75 ml/kg seed of chickpea resulted in no adult emergence and seed damage by $C$. chinensisupto 160 days of storage. Rahman and Talukder (2006) observed that the powdered leaves and extracts of nishinda, eucalyptus and bankalmi at 3 $\%$ mixture provided good protection for black gram seeds against $C$. maculatus by reducing insect oviposition, F1 adult emergence and grain infestation rates. Six vegetable oils viz., mustard, neem, karanj, cedar, apricot and olive were evaluated for protection of pea seed from pulse beetle, Callosobruchus chinensis L. The minimum number of eggs (4.78 eggs/5 females) recorded in neem oil coated seeds was statistically at par with karanj (6.67eggs/5 females). Minimum adult emergence ( 0.56 beetles) was recorded in neem oil coated seeds was statistically at par with karanj $(0.89$ beetles) after sixty days of treatment (Bhardwaj and Verma 2012). Singh and Sharma (1982) reported an increase in the uric acid content of moong and mash 
Jagtar Singh et al. / J. Appl. \& Nat. Sci. 9 (4): 2110 - 2113 (2017)

Table 3. Effect of different concentrations of traditional products on uric acid content of mungbean during four months of storage.

\begin{tabular}{|c|c|c|c|c|c|c|}
\hline \multirow[t]{3}{*}{ Treatment } & \multirow{3}{*}{$\begin{array}{l}\text { Concentration } \\
(\%) \text { w/w (B) }\end{array}$} & \multicolumn{4}{|c|}{ *Uric acid content $(\mathrm{mg} / \mathbf{1 0 0 g})$} & \multirow{3}{*}{ Mean } \\
\hline & & \multicolumn{4}{|c|}{ Storage period ** (MAT) (A) } & \\
\hline & & 1st & 2nd & 3rd & 4th & \\
\hline \multirow{3}{*}{$\begin{array}{l}\text { Turmeric } \\
\text { powder }\end{array}$} & 0.5 & 37.52 & 40.74 & 47.33 & 67.64 & 48.31 \\
\hline & 1.0 & 36.24 & 38.92 & 45.67 & 64.72 & 46.39 \\
\hline & 2.0 & 34.55 & 36.17 & 41.37 & 58.84 & 42.73 \\
\hline \multirow[t]{3}{*}{ Turmeric grits } & 1.0 & 37.71 & 41.46 & 54.83 & 75.27 & 52.32 \\
\hline & 1.5 & 36.54 & 40.37 & 51.27 & 72.32 & 50.12 \\
\hline & 2.0 & 35.76 & 38.49 & 47.24 & 67.62 & 47.28 \\
\hline \multirow[t]{3}{*}{ Garlic powder } & 0.5 & 35.13 & 39.77 & 45.63 & 61.97 & 45.62 \\
\hline & 1.0 & 34.55 & 38.44 & 44.83 & 54.77 & 43.14 \\
\hline & 1.5 & 32.17 & 35.28 & 40.15 & 45.88 & 38.37 \\
\hline Standard check & - & 30.75 & 30.85 & 31.07 & 31.52 & 31.05 \\
\hline Untreated control & - & 41.82 & 49.77 & 67.88 & 97.95 & 64.36 \\
\hline Mean & - & 35.70 & 39.11 & 47.02 & 63.5 & - \\
\hline $\mathrm{CD}(\mathrm{p}=0.05)$ & & $\mathrm{B}=0.05$ & & & & \\
\hline
\end{tabular}

*Mean of three replications, **Months after treatment

varieties infested by $C$. maculatus after 5 months of storage the uric acid content was 838.28, 762.00, $402.46,224.00$ and $198.70 \mathrm{mg} / 100 \mathrm{gm}$ of seed in shining moong No.1, G-65, ML-5, Mash 1-1 and Mash T-9 respectively. As in our study, turmeric powder, turmeric grits, garlic powder were found to be effective against pulse beetle in mungbean and on the basis of above mentioned references we can say that plant products can play a better role as grain protectants but there is need to aware the farmers about their utility and focus towards the commercialization of these plant products.

\section{Conclusion}

In the present investigation, treatments with garlic powder at $1.5 \%$ concentration recorded significantly less egg laying (2.00), less larval penetration (5.00\%), less adult emergence $(1.02 \%)$ as compared to other treatments. Garlic powder was found to be most effective in checking uric acid at concentration of $1.5 \%$ during four months of storage, followed by turmeric powder (a) $2.0 \%$ and turmeric grits @ 1.0\%.These traditional products can be used as a tool to manage pulse beetle infestation so as to improve marketability and acceptability of pulses. Furthermore, plants of insecticidal value are locally available and their preparation by drying and powdering is practically possible at village level.

\section{REFERENCES}

Anonymous (2014). Area and production of mungbean in India. (http://www.indiastat.com)

AOAC.(1960). Official Methods of Analysis. Pp. 162-64. Association of Agricultural Chemists, Washington.

Aslam, M., Zia, A. and Shaheen, F. A.(2004). Efficacy of some plant materials against stored chickpea beetle, Callosobruchus chinensis Linnaeus. Pak J Arid Agric., 7: 215-217.
Bhardwaj, A. and Verma, S. C. (2012). Evaluation of vegetable oils against pulse beetle, Callosobruchus chinensis (Coleoptera: Bruchidae) infesting pea seeds (Pisum sativum 1.). Pest Mgmt Hort Ecosystems 18: 46-53.

Cheema, H. S. and Singh, B. C. (1990). A User's manual to CPCS 1, Pp. 46 Punjab Agricultural University, Ludhiana.

Kar, A., Ganguli, J. and Ganguli, R. N.(2012). Testing of few botanicals as leaf powder against oviposition of pulse beetle, Callosobruchus maculatus (Coleoptera : Bruchidae) on chickpea kabuli variety dollar. J Ent Res 36: 334-338.

Mehrotra, K. N.(1991). Current status of pesticide resistance in insect-pests in India. $J$ Insect Sci., 4: 1-14.

Pajni, H.R. (1987). Ecological status of host range and polymorphism in bruchidae. In Proceedings of the Fourth International Working Conference on Stored Product Protection, Tel Aviv, Israel, 21-26 September 1986 (edited by Dorahye E and Navarro S) Bet Dagan, Israel. Agri Res Org., 506-16.

Rahman, A. and Talukder, F. A. (2006) Bioefficacy of some plant derivatives that protect grain against pulse beetle C. maculatus. J Insect Sci., 6:1-10.

Ramazan, M., Chahal, B. S. and Judge, B. K. (1990). Storage losses to some commonly used pulses caused by pulse beetle, Callosobruchus maculatus. J Insect Sci., 3: 106-08.

Sharma, R., Devi, R., Sharma, R. K. and Mehla, J. C. (2013) Efficacy of some botanicals against pulse beetle, $C$. chinensis (L.) in chickpea. Legume Res 36: 125-30.

Singh, D. P. and Sharma, S. S.(1981). Studies on weight loss in different varieties of moong and mash during storage caused by Callosobruchus maculatus (F.) (Coleoptera: Bruchidae). Bull Grain Technol., 19: 194-97.

Singh, D. P. and Sharma, S. S. (1982). Studies on the grain damage and germination loss caused by $C$. maculatus (Fab.) in different varieties of moong and mash during storage. Bull. Grain Technol., 20: 20-24.

Thaper, V. K., Paul, B. and Singh, R.(1973). A calorimetric method for assaying uricase activity in plant material. Indian J Agric Sci 43: 536-38. 